\title{
The music industry \& its consumers: A potential divorce through technology and shifting market linkages?
}

\author{
Klaus G Oestreicher, Joanne Kuzma \\ (Worcester Business School, University of Worcester, Worcester WR2 6AJ, United Kingdom)
}

\begin{abstract}
A large market exists of online users who desire online video and music content. However, recent developments have shown that some industries, such as music and videos are not fully utilising the market benefits that disruptive technologies can bring to organisations despite the change of value drivers. According to Christensen et al (2004), and based on RPV theory, organisations may decide not to pursue disruptive innovative ideas for a variety of reasons, such as their values are set in another direction, processes do not support the new technology and resources may become under-utilised or even obsolete. Trying to pursue partly aggressive strategies, partly defence or avoidance strategies, it is suggested that the music industry has missed to reengineer its business so far. At the same time, music consumers have found various peer-to-peer models to execute their own avoidance strategies, i.e., avoiding to buy music but to share it. Various consumption platforms for music, such as, pandora, hulu or spotify, emerged, which themselves show significant innovative power. As scholars' research tested, innovation has two beams, technology and market linkages. While the technological part is inevitably developing further, the music industry erects legal barriers to bloc those sites by applying the presently unclear DRM, since the new ways of music consumption threaten their established ways of content distribution. At the same time, barriers are placed that those consumers being online specialists find ways to circumvent them. The proposition is that by the salient marketing concept of CRM such behaviour increases the pressure on incumbents since risking market linkages with their customers. This paper will contrast technology and market linkages, discussing how online innovations may alter the status quo of the music industry, especially its record business. Research provides evidence that technological implications are supporting a sustainable shift of consumers' behaviour and the ways, by which consumers are able to overcome the legal and technological barriers for accessing P2P sites despite industrial prevention. It is suggested that there is further significance this paper addresses, since what affects the music industry today, will likely have an impact on the movie, games, software and other industries in the near future: Disruption of existing resources, processes and values and threatening market linkages by redefined ways of content distribution.
\end{abstract}

Key words: disruptive innovation; RPV theory; P2P; technological barriers; market linkages

\section{Introduction}

In 2002, pop-icon David Bowie resumed that everything we thought about music will be completely changed in the next years and that copyrights will belong to the past. Music itself will be available like water or electricity

\footnotetext{
Klaus G Oestreicher, senior lecturer in international business, Worcester Business School, University of Worcester; research fields: innovation and corporate strategies.

Joanne Kuzma, Ph.D., senior lecturer, Worcester Business School, University of Worcester; research field: information systems.
} 
(Kusek, et al., 2005, p.3). In 2009, music is available "everywhere" but the copyright dispute between the music industry, composers, artists and consumers is far away from coming to terms. The Digital Rights Management (DRM) is an unresolved dispute despite that US courts have strengthened the position of intellectual property owners. Other countries' court decisions resulted in confusion for IP owners (Benghozi, 2006; Dodgson, et al., 2008, p.293; Trott, 2008, p.146). Von Lohmann (2009) indicates that the entertainment industry (such as music and video) has a long history of fighting disruptive technologies, even though these same technologies have spawned new industries, consumer products and services, and enriching the same industry that attempts to suppress it. These technological developments including the latest ones follow Schumpeter's theoretical approach of the wind of creative destruction (Schumpeter, 1950, pp.81-87). As early as the 1900's, the industry attempted to disrupt technology by putting a new invention—-the player-piano, under its sole control. Throughout the 20th and into the 21st century it attempted to suppress innovations such as the VCR, DVD and online downloads with a combination of technology, copyright and legislation barriers. Von Lohmann further explains that the industry even has petitioned the U.S. Congress and the Federal Trade Commission to regulate the design of some disruptive technologies, such as innovations that can receive and record digital television and radio broadcasts.

Consumers taking advantage of download offers are unlikely to be safe or protected against organisational accusations of having committed an act of piracy. In its approach to maintain and restore the status quo the music industry takes legal action against downloading consumers in many countries. This sheds some light on this industry's dilemma: Marketing theory propagates CRM as a most important concept for reputation, image and loyalty for repeated purchase within hyper competition. Therefore it needs to be questioned, how the music industry can be able to establish relationships with the same customers they threaten legally? At the same time there is the paradox of marketing intensively products to these target groups, which are frequently accompanied by promotion campaigns presenting scenes of criminal and arrested persons. Since love marks play an important role within the corporate set of intangible assets, it seems unlikely that in such context consumers are prepared to accept partner or relationships with this industry. Missing values of sympathy are unlikely to further intangible assets like reputation and image. The hypothesis is that little sympathy and loosened relationships make it more likely to accept different offers for the same product, proposing that the industry's institutional behaviour is counterproductive for its intended outcome making it even more difficult to compete with virtual, dematerialised files by physical products in a then discontinuous environment initially caused by disruptive innovation. Permanently decreasing sales figures challenge this industry's established business models, especially its distribution chain as a major source of revenues. The threat of becoming obsolete in the business of pre-recorded media is considered as being realistic, since digital dissemination of dematerialised products allows disrupting this chain at any level and to address the consumer, the value chain's final point, by various channels directly (Benghozi, et al., 2000).

There is evidence that the origin of this changed context can be found in discontinuous or disruptive innovation, which the Internet's new opportunities created. Innovation's two beams, technology and market linkages, seem both to play an important role in the music industry's present dilemma. Von Hippel (2005, p.118) highlights that users innovating and wishing to freely diffuse are able to do so cheaply in large part because of steady improvements in Internet distribution capabilities, frequently using P2P sharing networks. Such capabilities provide a different cost structure to that of corporate distribution channels and systems. Such structural cost difference is expected to be difficult to outbalance within the established distribution system of corporate music dissemination. 


\section{Innovation and its influences on the music industry}

It is suggested that a brief discussion about innovation as a multidimensional phenomenon allows better explanation of the music industry's paradoxical behaviour. Literature discusses various degrees of innovation (see Table 1), which have different impact on organisational resources and capabilities [R\&Cs] (Abernathy, et al., 1983; Utterback, 1996; Christensen, et al., 2004; Chesbrough, 2006a; Chesbrough, et al., 2008; Von Hippel, 2005; Fagerberg, 2005; Ettlie, 2006; Davenport, et al., 2006). The proposition of considering innovation as multidimensional respects that it can have various attributes simultaneously: Innovation can, e.g., be radical and open, or conservative and closed. While the lower degrees of marginal improvements or changes may result in a process of adaptation, the more radical degrees may challenge and stress an organisation's or even an industry's established resources and capabilities up to the need of adopting and developing new resources, capabilities and processes to supply changing market demand with new and different products and services. Furthermore the consideration of innovation's two streams, technology and market linkages seems evident proposing further evidence for the notion multidimensional. Within a process of innovation the one or the other stream may change, but when both shift from one technology to a different one and business models or consumer behaviour change at the same time, then the threat becomes substantial. One relatively early example is the Napster platform for P2P file exchange (Tidd, et al., 2005, pp.45-47). Napster's impact on the music industry comprises both streams: Technological innovation (Internet and MP3 files) and market linkages (P2P exchange). Hence multidimensional, consecutive innovation causes an emergent situation, which sets the music industry's business model on risk. Additionally the legal reluctance of regulatory bodies to declare such exchange generally as an act of copyright infringement undermined market structures further resulting in the threat of disruption of established processes being based on this industry's R\&Cs.

Table 1 Grades and forms of innovation

\begin{tabular}{|l|l|}
\hline Disruptive & Destructive effect on existing technologies \\
\hline Radical & Degree of substantial novelty \\
\hline Incremental & Degree of less important novelty (improvement) \\
\hline Sustainable & Discontinuous or radical nature \\
\hline Architectural & Technological or process advances fundamentally changing a business component or element \\
\hline Conservative & Extension or refinement of existing technologies \\
\hline Epochal & Disruptive and substantial improvement \\
\hline Modest & Degree of small significance \\
\hline Open & Innovation using internal and external discoveries \\
\hline Closed & Innovation developed by own R\&D \\
\hline
\end{tabular}

Adomavicius et al (2008, p.789) suggest that relevant digital innovation has become an accelerating sequence of major inaugurations (see Table 2). The conclusion this model proposes is that these innovative processes are:

(1) Different to the industry's established model, especially distribution and dissemination of content;

(2) Technology offers consumers wider and extended use of alternative opportunities;

(3) Convergent technology alienates consumers' behaviour from established distribution channels further.

Trott (2008, pp.29-31) supports this argument by the example of the iPod transforming the ways the public listens to music with huge ramifications for the major record labels. Kusek et al (2005, pp.4-6) dare to predict that in 2015 not only music, but as well videos and games, will be available permanently, dematerialised and based on flat rate models. But they argue, too, that the major industry will fight for maintaining its status quo. This leads to 
the hypothesis that:

(1) Present strategies of this industry are decisively challenged, since losing fit with market realities unable to meet shifting consumer behaviour;

(2) Established resources and developed capabilities, R\&Cs of distribution, may become obsolete.

Table 2 Sequence of innovations and market approaches for dematerialised music products

(Adomavicius, et al., 2008, p.789)

\begin{tabular}{|l|l|}
\hline 1989 & German MP3 patent \\
\hline 1996 & US MP3 patent \\
\hline 1998 & First portable MP3 player (32MB) \\
\hline February 1999 & Sub Pop distributes MP3 music \\
\hline May 1999 & Napster founded \\
\hline May 2000 & Transactional watermarking founded \\
\hline January 2001 & Napster injunction \\
\hline October 2001 & 10 GB Apple iPod introduced \\
\hline March 2002 & 20 GB iPod for PC introduced \\
\hline April 2003 & 40 GB iPod introduced \\
\hline October 2003 & Dell DJ introduced \\
\hline & iTunes online music store opens \\
\hline September 2004 & MSN online music store opens \\
\hline May 2005 & Yahoo online music store opens \\
\hline October 2005 & First iPod with video capabilities \\
\hline August 2006 & 160 GB 1.8 inch HDD introduced \\
\hline September 2006 & iTunes starts sales of full-length videos \\
\hline July 2007 & iPhone (MP3 player/phone) introduced \\
\hline September 2007 & 160 GB Video iPod introduced \\
\hline
\end{tabular}

\section{The impact on the value chain}

The music industry is by far not the only industry struggling with disruptive innovation creating a discontinuous environment. Assink (2006) defines disruptive technologies as: A successfully exploited radical new product, process, or concept that significantly transforms the demand and needs of an existing market or industry, disrupts its former key players and creates whole new business practices or markets with significant societal impact. According to Hagel et al (2008), we live in a world of massive technological change creating a new techno-economic paradigm that will shift the fundamental way firms engage in business. Many new innovations, such as the mobile telephone and Internet have created new opportunities, and these disruptive technologies transform industries and commerce. However, these rapid changes result in a business model where changes are so constant and rapid (concept of permanent change) that industry and technology cannot be stabilised. Instead, the authors argue that businesses constantly find themselves in a situation where they continually race to catch up with and learn the steadily improving foundational technologies (concept of the learning organisation).

The typewriter industry, the photo industry's shift to digital photography or the destroyed VHS industry is just three examples out of many, which may hence be considered as casualties of disruptive technologies. Utterback (1996) argues that managers' action is usually directed towards competitors' activities, but that the most threatening challenges are frequently coming from outside. Christensen et al's research presents the resources, 
values and processes theory (RPV), which may provide a theoretical underpinning, why organisations frequently fail when confronted with disruptive innovation (Christensen, et al., 2004, pp.279-280). The RPV-theory tends to hold that resources (which companies can buy or sell, create or destroy), processes (established ways of transforming resources into products and services) and values (the prioritisation criteria of the management within the decision making process) do not favour the emergent technology and/or business model. But if they do not leverage these new technologies, their current products may become commodities and they risk their long-term survival as competitors take advantage of these disruptive technologies to meet consumer's needs and wants. The processes and values of established firms differ to those of companies willing to take competitive advantage of disruptive technologies.

The meaning is that as long as innovation does not exceed incremental improvement within established RPVs, e.g., from CD to Music DVD or SACD, it is easy for incumbents to follow the new technology. The channels of distribution and purchase remain stable, the product is still physical and the selection of content presented to consumers is the industry's choice forcing consumers to accept pre-recorded propositions, which cannot be altered with regard to individual taste. When the digital CD replaced the analogue vinyl record in the early 1980's the medium changed radically due to digital technology, manufacturers of vinyl records became obsolete, but the way of creating and distributing products remained as stable as their consumption. This suggests in the understanding of innovation that the technological shift was epochal and radical. The CD replaced the vinyl record as dominant design but market linkages remained untouched. Therefore this shift was relatively easy, since the advantages of the digital technology were attractive and logic to consumers. Hence both ends of the market achieved a rather quick congruence and the industry’s R\&Cs and its chain of values remained persistent.

A second theory Christensen et al (2004, pp.277-279) suggest is the disruptive innovation theory. Ettlie (2006, p.78) criticises this theory as too much concentrated on market leadership. But with regard to the music industry it needs to take into consideration that an oligopoly of four companies owns app. 85\% of the market share. Therefore sufficient validity and reliability is proposed for applying this theory here. Three of its major criteria are considered of having specific importance in this context:

(1) When disruptive innovations emerge, their quality is usually inferior to that of established products: Initially downloads demanded long times due to low broadband capacities and frequent breakdowns; the sound quality of MP3 files on computers was below that of the established CD played on hi-fi devices.

(2) The emerging market was so small that incumbents did not consider it as important:

The initial download market did not create sufficient business until broadband lines offered enhanced capacity and broadband lines as medium of transportation became accessible to a majority of the population. Further, these latter incremental improvements depended on an additional technological vehicle, new players of broadly accepted sound quality to make dematerialised products attractive to a majority of consumers.

MP3 players became especially fashionable by Apple’s iPod (technology) and, (market linkages) when Apple opened its iTune store (Anderson, 2006, p.39). This may be considered as the turning point, when virtual products became advantageous for many consumers.

(3) When the market starts to threat established companies they tend to flee upmarket:

With regard to the music industry's strategic behaviour this criterion may have further specific importance. It generally expresses that threatened industries tend to increase incremental improvements: E.g. from CD to SACD and Music DVD (technology) or by adding bonus material or offering luxury editions (market linkages). This works as long as consumers are prepared to pay a premium for it. Christensen et al present two trajectories 
representing the overshot and the undershot customers. When incremental improvements start to overshoot customers' expectations they will not honour the premium charged anymore. This argument is supported by Kelly's thesis "follow the free" (1997).

It is suggested that such incremental improvements were generally in vain, since competing against free of cost P2P downloads. The SACD became never a market success. Its further disadvantage was a lacking compatibility with regular CD-players, demanding further consumer investment.

Concluding these arguments suggests that initially downloading was neither a threat, nor an interesting business for the established industry. Technologically and by sound quality far inferior, difficult and unreliable to access the industry would probably have caused more damage to itself than attracting additional business. When this situation changed, it was too late—-similar to various studies about other industries. There are some arguments to consider Apple's combination of iPod, MP3 and iTunes as the breakthrough point with both the power and ability to affect the whole chain of values and attracting further companies of substantial power, like, e.g., Yahoo and MSN, from outside the music industry all widening the virtual market space by augmented accessibility, easiness of use and immediate consumption. It is suggested that an additional barrier against incumbents' opportunities to flee upmarket is seen in the 1:1 delivery of content of individual preference avoiding the purchase of unwanted tracks. Therefore, the proposition is that the new opportunities for consumers, downloads and free exchange of digital files, are steadily growing by:

(1) the size of offer of available tracks;

(2) the individuality of purchase selection;

(3) the low or 0-cost models;

(4) the increased easiness of access;

(5) convergent technologies, e.g., the iPhone, and the commodity of transporting and exchanging files on and for multiple players.

This may disrupt the music industry's distribution chain resulting in discontinuous revenues then, i.e., when the new business model replaces the established ones, and the value chain will need to be completely reengineered. Utterback's research in various industries has provided evidence: When a (new) dominant design is established the total number of firms declines steadily (Utterback, 1996, p.33).

\section{Factors of institutional control and strategic behaviour}

Karp (2003) argues that laws were passed forcing manufacturers to include mechanisms to prevent copying a copy in some technologies, such as DAT tapes. This had the effect that this technology never achieved large market share and new business models could not be implemented because of these legal limits. According to Lampel et al (2008) intellectual property rights are a major cause for firms in inadequately dealing with disruptive technologies. When these firms are faced with these types of threats, they often engage in offensive and defensive strategies in order to change the industry environment.

Moyon et al's research provides evidence that the industry majors' role as privileged intermediary is endangered by new entrants' different structure of doing business, which is due to Utterback, Christensen and Christensen et al significant with regard to disruptive innovation trajectories (1996, 2003, 2004, 2004, 2007). Moyon et al suggest that until 1997 the industry's major participants were in control of the business's key elements, dissemination and format (see Fig. 1). This model addresses the institutional control of the value chain, 
artists, content produced and offered, products and points of sales. This business model leaves consumers with little influence and choice in comparison to the plenitude, which Internet offers provide (Kelly, 1997).

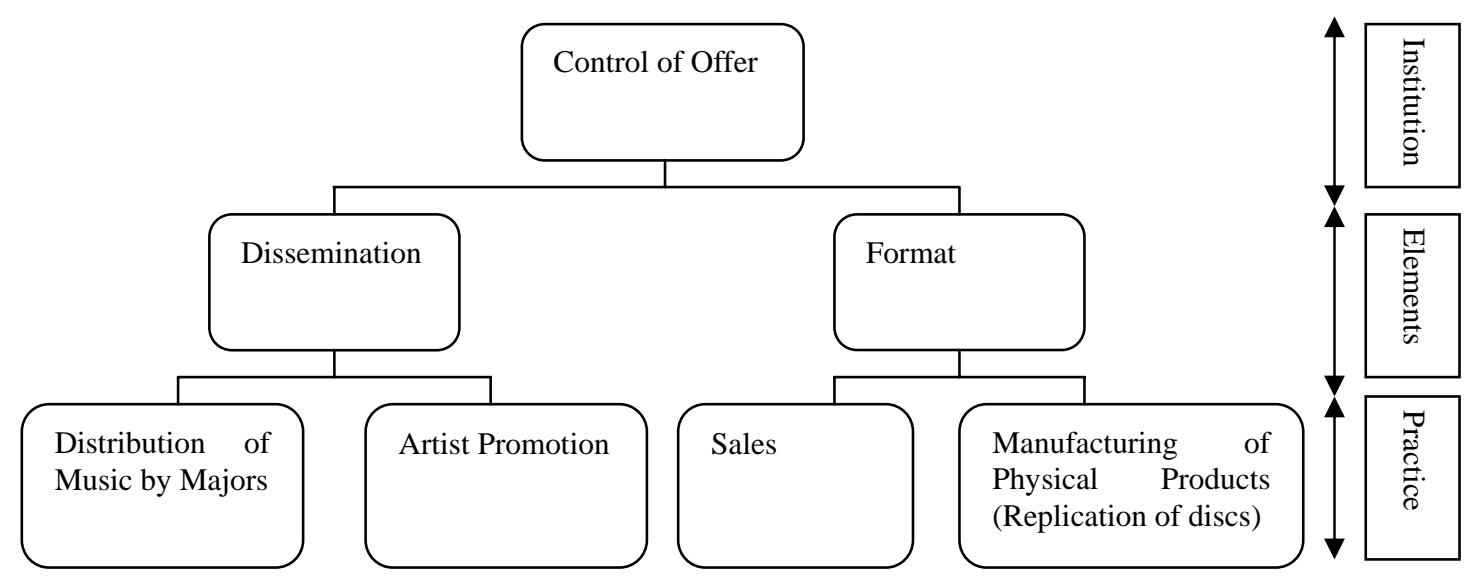

Fig. 1 The music industry's established model of control (Moyon, et al., 2007)

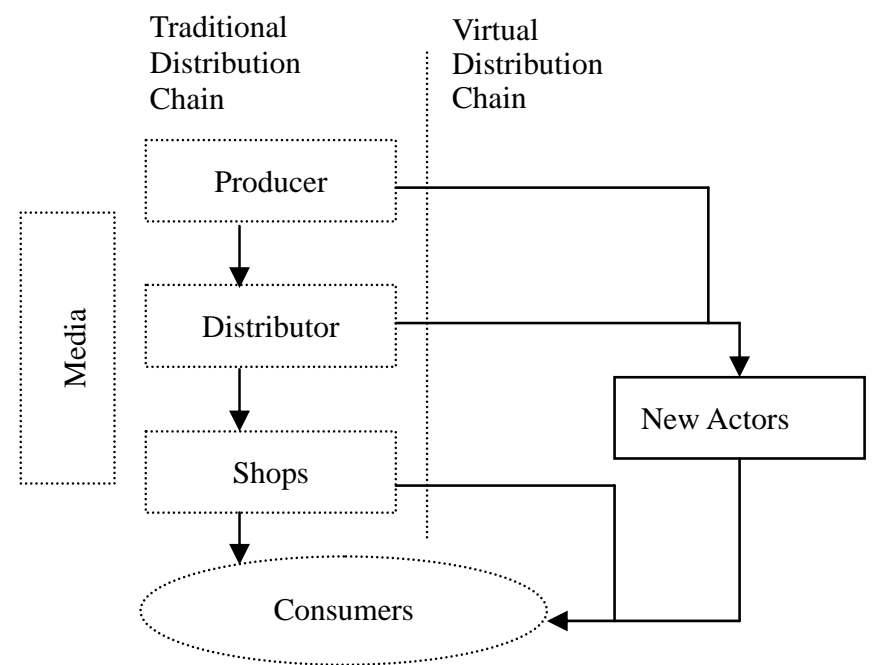

Fig. 2 The virtual and physical distribution chain, adapted from Benghozi, et al, 2000

E.g., it was the music industry's sole decision to place tracks on an album. It is common practice to mix hits with less successful music. This way, so the proposition, earlier failed productions created a ROI, too, as consumers could not avoid their purchase. Nowadays, the new technology empowers consumers to download selectively those tracks only, which are of individual interest. This is suggested as an act of consumer democratisation. So, power shifts to consumers, the prosumer concept may play a role by creating own compilations, and organisational control and options for profit maximisation are reduced (Kotler, et al., 2002). Similarly artists depended on contracts with record labels and their marketing budget allocated to them. P2P models and with regard to artists' frequent amateur or semi-professional status, C2C models as well allow direct business between artists or producers and consumers, enabled by communities, sharing platforms or free presentation like YouTube and the option to exclude the established industry: The new chain of distribution allows interruption of the traditional one at any level (see Fig. 2). Dematerialised products support the reduction of organisational control of formats and products, a situation that is expected to increase over the next years. The proposition is that three of four components are decreasing institutional control and have effects on the fourth, sales, i.e. revenues. 
Table 3 Highlights of online sales and physical decline

- Music purchases (transactions) in 2008 reached 1.5 Billion, marking the fourth consecutive year music sales have exceeded 1 bill ion; 1.4 billion (2007) vs. 1.2 billion (2006) vs. 1 billion (2005).

- Overall Album sales (including Albums and Track Equivalent Album sales) declined $8.5 \%$ compared to 2007.

- Total Album sales declined $14 \%$ compared to 2007.

- Metallica's "Death Magnetic" is the best selling Internet album for the year with 144,000 sales.

- During 2008, more Vinyl Albums were purchased (1.88 million) than any other year. The previous record was in 2000, with 1.5 million LP album sales.

- Digital Track sales break the 1 Billion sales mark for the first time with more than 1,070,000 digital track sales. The previous record was 844 million digital track purchases during 2007; an increase of $27 \%$ over 2007.

- Digital Album sales reached an all-time high with more than 65 million sales in 2008; up from 50 million in 2007; an increase of $32 \%$ over the previous year.

- Digital album sales account for $15 \%$ of total album sales compared to $10 \%$ in 2007 and $5.5 \%$ in 2006 .

- 2008 is the first time a digital song broke the 3 million sales mark in a single year. Leona Lewis' "Bleeding Love" and Lil Wayne's "Lollipop".

- In 2008, there are 19 different digital songs with sales that exceeded 2 million compared to 9 in 2007.

- 71 Digital Songs exceed the 1 million sales mark for the year compared to 41 digital songs in 2007, 22 in 2006, and only 2 digital songs in 2005 .

- Rihanna is the biggest selling digital artist in 2008 with nearly 10 million track sales compared to Fergie in 2007 who had 7.5 million track sales.

- There are more than 450,000 different physical albums that sold at least one copy over the Internet during 2008 compared to 390,000 in 2007.

(Nielsen Company Soundscan report for 2008 cited in Kusek. 2009)

As long-term statistics provide evidence, the record business is in annual decline resulting in permanent substantial decrease of sales figures (see Table 3) (Anderson, 2007, pp.35-39; RIAA, 2005; RIAA, 2006; RIAA, 2007; RIAA, 2008). Replication factories report about significantly shrinking orders for both new releases and catalogue products (Killer-Korff ${ }^{1}$, 2008; Eras $^{2}$, 2008). The physical album still counts as the major economical factor, but this status is challenged here, since free of cost exchange and transactions are difficult to count and calculate and the assumption is that a huge number cannot be controlled at all due to its mere quantity and frequently taking place in privacy. Anderson's contrast that $[>] 10$ Mio online users are exchanging files each day, while from 2001 to 2005 the sales of the music industry declined by 25\% shows the difference between record and music business (Anderson, 2007, pp.35-39). Hence, so the argument, the record business is in decline, but the music business is more likely to be growing (see Table 3). This differentiation seems important in the way to understand the music industry as a set of various businesses. An underlying paradox is that for the album-driven (CD) institutional participants markets shrink, while for creative participants, artists and producers, and for consumers ICT offers enlarged opportunities of growth and direct collaboration outside industrial control and potential limitations.

As outlined in the beginning, the music industry tries to maintain its status quo mainly by taking legal action against various forms of downloads, either against individuals or those offering platforms and exchange networks. Applying Oliver's hypothetic model, the proposition is the industry's main implementation of the strategies:

(1) Defy especially using the underlying tactics of "assaulting the sources of institutional pressure"

(2) Manipulate especially using the tactics "co-opt”, importing influential constituents, e.g., government regulations and courts (Oliver, 1991, p.152).

A first summary resumes the following propositions:

(1) With reference to the expression that "what was invented cannot be made un-invented" downloads have

\footnotetext{
${ }^{1}$ Killer-Korff, P., regional sales manager at CDA Datenträger Albrechts GmbH, personal conversation September 2008.

2 Eras, J. U., manger sales at kdg-mediatech AG, personal conversation July 2008.
} 
become both a real pressure and an economic factor directly competing with the record industry, which are unlikely to be suppressed anymore.

(2) Further marginal improvements of the Internet, but as well the near introduction of Internet 2 will enhance easiness and access further creating extended and faster opportunities of access to music.

(3) Each of these innovations may lead to a further loss of market linkages, if the record industry maintains its present strategic framework and fights mainly for its status quo.

(4) The record industry is unlikely to maintain this status quo, i.e., especially the control of markets, market offers and distribution in the future.

(5) Virtual products will replace CDs as dominant design in the very near future, but niches for so-called special interest music (audiophile and non-mainstream music) will remain to be exploited, especially at the upper end of the markets.

(6) “Companies that don’t realize their markets are now networked person-to-person, getting smarter as a result and deeply joined in conversation are missing their best opportunity” (Levine, et al., 2001, p.23).

(7) I.e., the corporate behaviour of threatening consumers taking advantage of dematerialised download offers alienates them and creates for institutions both a negative image and reputation.

\section{The institutional and non-institutional music industry}

Studies have shown that when industries implement technological and legal strategies to hinder consumer access to products, consumers find work-around solutions to illegally acquire the products. This can have a negative impact on total industry sales. In 2001, Zenter (2006) performed a study on the effects of music downloads on the probability of purchasing music using 15,000 Europeans. He found that peer-to-peer-downloading reduces the probability of legally buying music by 30 percent, and calculated that without downloads, sales in 2002 would have been 7.8 percent higher. Thus, if the entertainment industry made better use of the disruptive technologies in altering their business models to entice these consumers not to engage in illegal downloads the industry could gain a significant amount of sales.

However, although many firms in the entertainment industry are limiting consumer access to services because of the industry fears of disruptive technologies adversely affecting profits, it should be noted that some valid economic reasons exist for not offering services. For example, firms providing download content often make more money by advertising rates on sites than by income provided by download subscriptions. Worldwide there are 1.6 billion people with Internet access, but fewer than half have incomes sufficient to interest major online advertisers. Thus, in developing countries where bandwidth is expensive but advertisers do not see the value in paying for online ads, entertainment providers may decide it is economically more practical to shut off services. However, some firms have found ways around these challenges by using stripped down versions of the sites requiring less bandwidth (Stone, et al., 2009). Thus, although downloads to these consumers may be slower, they still would have access to the content.

Outside organisations there are enthusiasts creating access opportunities via combined technology. One of these is pandora.com representing download + search engine $+1: 1$ and micro "communication" . In brief, this platform recognises a huge number of music tracks by categories out of a database, which music experts have created. Users' priorities, subject to individual taste, help pandora to refine the individual profile leading to

\footnotetext{
${ }^{3}$ Westergren, T.. Pandora internet radio, retrieved from www.pandora.com.
} 
automate new propositions. The pandora site is meanwhile blocked outside the USA despite its path breaking richness and accuracy. The development of pandora was made by music professionals in collaboration with IT experts under direction of Westergren investing over 150,000 hours creating a community of music fans outside the music and especially record industry (Ahmia, 2005). As Ahmia resumes, such creativity must shame the big bosses of the world's major record labels and that with a vision new business models (market linkages) can be created. Despite the team around pandora is not a consumer community a link to Antorini's theory that "consumers fill in the spaces firms leave open" is drawn, since it is proposed that institutional record labels missed a chance of future orientation and innovation of its revenue streams by not taking advantage of such “community” expertise (Antorini, 2007; Antorini, 2009). Antorini (1999) may further be linked to Popcorn’s concept of clanning, i.e., individuals with similar interest and taste will find each other.

The assumption is that non-institutional knowledge does not only develop creative new paths of circumventing technological barriers, its richness of ideas finds solutions, which are filling the blank spots organisations inherit. These ideas allow doing business among community members, P2P and C2C organised, by an own set of shared values and believes but often enough explicitly excluding organisational parties.

The music industry furthered communities, which are not an effect of latest innovation. They exist since a long time and are often organised in fan groups being communities per se. Previously the music industry welcomed these organised fans highly since being a concentrated, easy to target and influence word-of-mouth promotion and mind setting tool; i.e. clanning took place even before the emergence of ICT. Now, when artists upload specific songs inviting their fans, those communities, to download them to listen to latest creations, record labels to which these artists are assigned frequently act offensively against those artists offending both artists and their communities. A reference is made to the David Bowie interview and leads to the hypothesis that such artist fan relationships may result in the establishment of direct market linkages between artists and/or producers and consumers and undermine organisational distribution and control of product additionally. Kusek et al (2006, pp.12-18) compare these relationships with the times before media, when music was a service and not a product.

The various non-institutional processes of music dissemination may have fuelled the fragmentation of markets. E.g., in 2000 the five best selling albums achieved a total sales figure of 38 Mio units, while in 2005 the five best sellers decreased to total sales of 19.7 Mio units (Anderson, 2007). One reason is seen in the diversification of consumer tastes, which the plenitude of the Internet may have supported resulting in a growth of sub-genres of music styles. But as well some initial research exists that non-institutional influenced ICT word-of-mouth propaganda influences click rates of specific songs strongly. It may be argued that the principle of communities, P2P recommendations and clanning can develop significant influences on market outcomes, which are not anymore controlled by the industry. The phenomenon of fragmentising markets is not specific to the music industry but a development affecting many other industries, too. In recent years, the music industry had developed fine-tuned ways of marketing, which made predictions of sales outcomes rather realistic. But when promotion outside these organisations may be stronger and more trusted and may hence have more influence than the organisational one the threat for sales and reliability of forecasts grows. Therefore it is suggested to understand the music industry's approach to suppress as many sites as possible to avoid uncontrollable mushrooming of clicks, downloads, recommendations and opinions. Once again a relationship is drawn to Oliver's hypothetical set of strategies, but whether such strategic and tactical outcome may lead to the desired results of stabilisation is questionable, since so far none of the actions taken could stop the decrease of sales.

To this adds the concept of hyper consumption, the permanent search for new experiences. Lipovetsky (2009) 
argues that some 20 or 30 years ago young consumers, a major target group of the music and record industry, proudly owned about 25 albums. Today, the same demographic group has stored thousands of songs on hard drives of different type. The proposition is that with regard to institutional product, distribution and revenue models in place only non-institutional, dematerialised dissemination of music allows such extensive collection of music and is dependent on the availability of online offers and P2P exchange.

\section{Recent developments restricting consumption}

A weakness of the entertainment industry with regards to RPV theory is that they are not embracing new download technologies and therefore alienating a huge number of potential consumers. A recent case is the removal of premium video music content from the YouTube site for users in the U.K.. YouTube is the world's most popular online video site, but in March 2009, it earned the wrath of U.K. consumers by blocking video downloads due to a failure to reach a new licensing agreement with the Performing Rights Society (PRS). YouTube stated that the issue of high-rates was an industry-wide problem, and that consumers would lose if the PRS set such high rates that new business models could not survive (Waters, 2009).

Another example of barriers consumers face when accessing online content is the case of hulu.com. This firm is an online site offering users the ability to download a variety of streaming video including full television episodes. However, European users of sites like hulu.com are prevented from downloading U.S. TV shows and other video content available to U.S.-based Web surfers. When potential consumers outside the U.S. attempt to access video content via the hulu.com site, they encounter the following message:

"Sorry, currently our video library can only be streamed from within the United States. hulu is committed to making its content available worldwide. To do so, we must work through a number of legal and business issues, including obtaining international streaming rights. Know that we are working to make this happen and will continue to do so. Given the international background of the hulu team, we have both a professional and personal interest in bringing hulu to a global audience" ${ }^{4}$.

In 2008, Veoh, a video-sharing site operating from San Diego, decided to block services from users in Africa, Asia, Latin America and Eastern Europe. The reason they cited was purely economics and profits, the prospects of making money from these areas was slim compared to the high cost of delivering services (Stone, et al., 2009). In January 2009, Pandora stopped streaming music to British users, after other countries had to be blocked earlier, because of unresolved royalty and licensing issues. Pandora sent an email to all users with a geographically based UK Web address informing them that the rates demanded per track by UK licensing authorities were too high to support, and service was being suspended (BBC News, 2009).

\section{Technologies to bypass barriers}

In order to protect intellectual property, prevent competition and defend the status quo, certain industry groups have imposed technical barriers on convergent downloading technologies. The result is that potential consumers are prevented from accessing online content, especially consumers who reside outside the U.S. However, consumers have shown a remarkable ability in finding methods to bypass these barriers.

Although a myriad of methods exist for bypassing copyright and other technology barriers, this paper limits

\footnotetext{
${ }^{4}$ hulu.com. (2009). hulu home page. Retrieved from http://www.hulu.com.
} 
itself to the discussion of two main methods related to bypassing online music and video downloads. There are two main categories of tools that online consumers can use to hide identity: connection-based anonymity and tools that hide the location or author of a particular Web document (Waldman, et al., 2000). Connection-based tools like the site www.anonymizer.com provide anonymity by acting as a proxy for users (Waldman, et al., 2000). For example, if hulu.com uses the UK users Internet Protocol (IP) address to block video content downloads from any IP address identified as a UK address, users can simply use the anonymizer site to make a request of that video. The anonymizer site "hides" the UK-based IP address from hulu, thus online consumers can bypass the censorship. Second, with author-based tools, users can install software, such as Janus, on their computers which functions similar to a connection-based tool in hiding the users personal IP address (Gaber, et al., 2006). Although Web surfers can use these types of tools to legitimately protect their privacy during Web browsing, in this case they often use it to bypass the downloading and surfing restrictions imposed by the entertainment industry.

A conclusion out of these examples is that consumers may always find ways to circumvent technological barriers. A comparison is drawn to the many copy protection systems on discs, which never were a final stop to prevent burning or downloading of a disc's content to computers. They may have been an obstacle but enthusiasts' expertise overcame these barriers rather quickly. So far none of the copyright protection systems could block unwanted dissemination or upload of content to the Internet. A decisive and economical question for the record industry is, whether the rather high investment in legal actions, copyright protection systems and other activities to protect its status quo has the power to protect it even in the mid-term. An argument for further research and reflection is, whether the focus on such avoidance strategies representing innovations' technological stream may not set the industry's market linkages, its other stream, on risk, i.e., the final balance of outcomes may be negative.

"The public benefits of peer-to-peer technology are self-evident: The ability to experience music and visual works at a fraction of the time and cost it would entail to travel to a local music store. Copyright holders, however, argue that the new technology has a rather unfortunate side effect: Peer-to-peer users are able to obtain copyrighted works for free” (Suppappola, 2004). This argument and its further discussion shed light on an overarching dilemma: There is a legitimate right of those having created intellectual property to be refunded providing sense to their work. Against this legitimate and tangible right stands a huge worldwide movement, which circumvents such right the one way or the other. The suggestion is that it is unlikely to stop this consumer practice anymore due to the extent it has achieved meanwhile. This is not equal to the attribution of legitimate or legal rights to the circumvention of barriers due to the mere quantity of downloads and Internet offers. But realistically and even more practically it is rather unlikely that such a global movement can be stopped. A further assumption is that the more institutional forces are trying to raise new or altered barriers, the more specific individuals and publics feel challenged to prove that such efforts will be in vain. Ballan (2001) suggests "in the absence of effective anti-circumvention technologies, the Internet has facilitated the rapid distribution of MP3 files containing unauthorized copies of popular songs". Taking into consideration that this problem could not be resolved in eight years time, supports the argument—without questioning legitimacy and legislation, that circumvention is an innovation by itself, which cannot be made un-invented anymore.

This suggests a further dilemma of the music industry, especially its business of recorded music. The legal and legitimate right of access to revenues for intellectual property and creative work has lost ground against shifting societal norms and values. An increasing number of consumers demand the right of access to free of cost and unrestricted and unlimited music, despite regulation or legal and technological barriers. As in all prior attempts of this industry's history once again it seems impossible that the music industry will be able to get 
innovation under its control, but this time, in the times of empowered consumers, the consequences may be much fiercer than before.

\section{What should the industry do to keep competitive advantage?}

A second conclusion, in a hierarchical cause and effect logic, resumes the presented argumentation and suggestions for the music industry and its business of recorded music (see Table 4).

Table 4 The presented argumentation and suggestions for the music industry and its business of recorded music

\begin{tabular}{|c|c|}
\hline $\begin{array}{l}\text { Disruptive innovation affects the music industry, } \\
\text { especially its record business, by its two streams } \\
\text { simultaneously: Technology (downloads and } \\
\text { dematerialised products) and market linkages (P2P sharing } \\
\text { and C2C exchange of dematerialised electronic files) }\end{array}$ & $\begin{array}{l}\text { Resources, p } \\
\text { differently tc } \\
\text { products, me } \\
\text { physical or v }\end{array}$ \\
\hline $\begin{array}{l}\text { Dematerialised products allow extensive mobility, are } \\
\text { compatible for multiple players, allow immediate access to } \\
\text { products, do not have delivery times, are fully mobile and } \\
\text { support extended experiential experiences }\end{array}$ & $\begin{array}{l}\text { esult in reduced institutional control } \\
\text { ways of doing business and by } \\
\text { ayments put augmented pressure on } \\
\text { s }\end{array}$ \\
\hline $\begin{array}{l}\text { tus quo and to avoid profit reduction } \\
\text { raises legal barriers and adopts passive } \\
\text { gies to bloc sites offering downloads, } \\
\text { owing the peer-sharing idea }\end{array}$ & $\begin{array}{l}\text { h techniques and technologies to } \\
\text { at the same time consumer creativity } \\
\text { spots and invents creatively models } \\
\text { e refined opportunities to discover } \\
\text { increasingly fragmentised markets }\end{array}$ \\
\hline $\begin{array}{l}\text { Fragmentised markets reduce established corp } \\
\text { opportunities to continue successfully and profitably } \\
\text { production and distribution of music within its exi } \\
\text { distribution channels based on institutional RPVs }\end{array}$ & $\begin{array}{l}\text { Despite uncl } \\
\text { models artists } \\
\text { addressing } \mathrm{c} \\
\text { disrupting th }\end{array}$ \\
\hline $\begin{array}{l}\text { ablished dissemination and } \\
\text { lenge corporate behaviour by } \\
\text { at protection devices and } \\
\text { s }\end{array}$ & $\begin{array}{l}\text { Dnal } \\
\text { and }\end{array}$ \\
\hline $\mathrm{e}$ & \\
\hline
\end{tabular}

There are several things the industry could do to utilise disruptive technologies and to maintain competitive advantage, yet allow consumers to better access to goods and services. First, it is useful to note that the industry needs to set up alliances with governments around the globe to combat piracy, which is in effect an agenda across industries. This would present a united front to the problem of piracy and illegal downloads, and would thus increase the legitimate use of downloading of music and videos (Lampel, et al., 2008). This means first of all channelling download activities in different sectors, those that are institutionally fully accepted, despite not being under corporate control, those that are at least tolerated and finally channels, which are definitely illegal, i.e., resolving the DRM problem globally. Second, the industry could consider forming alliances with firms to better use disruptive technologies and to create new business models. For example, firms in the current entertainment industry could form partnerships with Internet service provider firms or online communities such as Facebook to more effectively distribute the services to consumers, i.e., implementing a service and not only a product orientation. This would result in a division between creators and providers of services, each of which could provide market value, but working together. Third, incumbents can take advantage of the swarm intelligence. Instead of fighting creative forces like the Pandora team, they can invite these experts and commonly develop platforms of high attractiveness to consumers by adding new values, i.e. reengineering its value chain. 
This may lead to both sides’ profitable open source models. Chesbrough (2006b, p.131) argues that the Open Innovation Model is a firm's model that drives its search for innovation activities, whether using internal or external sources. This model favours useful technologies with the ability to advance the existing business by taking advantage of which sources ever create organisational progress, i.e. sharing or licensing of technologies becomes common practice. With reference to the RPV theory such institutional openness and culture may result in permanent adaptation of resources, processes and values to meet shifting market demands for the reduction of uncertainty in the industry's permanent struggle for survival. As Kusek outlines, a major problem is the consideration of music as a product and not as a service and as Lipovetsky argues, a physical product is likely less experiential than a mobile experience being mobile and accessible everywhere (Kusek, 2006, pp.36-40; Kusek, 2009). With reference to consumers' shift of consumption and expectations it is suggested that in summa the music industry is confronted with a consumer demand requiring augmented flexibility of corporate structures, processes and activities and with reference to its the record industry to reengineer its business from product orientation to becoming a service provider. This is by itself, so the further proposition, a radical and epochal re-innovation within this industry's RPVs. One important underlying criterion is a more flexible model of distributing revenues, different to the rather static model, which presently divides the consumer price of an album (100\%) to (in average) $8 \%$ for artists, $49 \%$ for labels, $8 \%$ manufacturing cost, $5 \%$ despatch and $30 \%$ for retailers (Kusek, et al., 2006, p.32).

The impact on managerial challenges, which an open business model causes, is substantial by cost, questions of power and control, learning curve and new orientation. Otherwise it needs to be questioned how long the present structure may be able to withstand the confrontation with such a different consumer orientation and demand. Various studies provide evidence for consumers being alienated by price structures of physical products and by institutional behaviour. Such behaviour may "divorce" organisations offering pre-recorded music from its market linkages, since the virtual, dematerialised offer grows permanently.

As a fourth and additional model using Porter's generic strategy of differentiation there is the opportunity to create many niche markets for audiophile music of special interest. There are consumers, who are interested in physical products, especially special editions of exclusive attractiveness. These consumers are expected to follow Christensen's upmarket design, i.e., preparedness is expected to honour luxury make up by a premium. These niches will not reach huge sales quantities but a high margin per unit. As argued before, the mega market for albums declined between the year 2000 and 2005 by around $50 \%$ and times since then provided further turmoil as statistics provide evidence for. Similar to other industries, fragmentised market developments are unlikely to stop in front of the music industry, which already has good strength and resources to work in an environment of diversified consumer tastes. Hence a strategic approach to increasing fragmentation seems unavoidable for survival. With the few exceptions of very few labels the record industry is in the need to acknowledge that consumers never bought labels but music styles and artists. Furthermore, the increasing degree of consumer mobility acts against the rather static dominant design of discs requiring one specific player, which cannot be reduced in size, while virtual files can be played easily on various devices and are as mobile as their consumers.

\section{Conclusion}

The music but especially the record industry is in a conflicting situation. Its resources, skills, processes and values are directed in a different way than consumer expectations. It is suggested that an adaptation, even if 
intended is rather difficult to achieve, since a transformation will be a difficult and delicate process. Incumbents are well structured for processes of exploitation of established ways of doing business and have problems of keeping pace with the accelerating development of the virtual market, for which space is more important than place (Markides, 2008, pp.168-170 ; Kotler, et al., 2002). On the other hand the simultaneous impact of technology and market linkages creates a dilemma, which does not only challenge the present models, especially distribution, it may rather quick culminate in a situation, which could result in obsolescence of present institutional structures. This may mean that a good number of incumbents will be unable to survive.

The proposition is that means and strategies to suppress new technologies will not be successful, but will alienate the customer base from institutional music providers further. The networking and frequently community organised consumer will quickly find and develop technologies and paths to circumvent technological barriers and is likely to ignore increasingly legal constraints, whether explicitly or implicitly since the DRM dispute remains unsolved yet. The assumption is that this may create an environment, where corporate image and reputation as important pillars of tangible institutional outcomes suffer further and consumers will increasingly refuse acceptance of relationships with product providers.

Instead of fighting against consumer driven innovation and development the industry is likely to achieve more positive outcomes by accepting the new organisational environment and seeking collaboration with the new driving forces despite that these are beyond its institutional control and different to its organisational resources, processes and values. This way it may be able to strengthen relationships by meeting demands of accessibility, mobility and consumer tailored content, which can provide future oriented extended experiences within the concept of hyper consumerism. The music industry is just one part of the complex Home Entertainment Industry and as a number of indicators show, the movie business and the games industry may be confronted with similar effects soon.

\section{References:}

Abernathy, W. J., Clark, B. K. \& Kantrow, A. M.. (1983). Industrial renaissance: Producing a competitive future for America. New York: Basic Books Inc.

Adomavicius, G., Bockstedt, J.C., Gupta, A. \& Kauffman, R. J.. (2008). Making sense of technology trends in the information technology landscape: A design science approach. MIS Quarterly, 32(4), 779-804.

Ahmia, T.. (2005). Spiel es für mich Pandora. taz. 19 November 2005. 17.

Anderson, C.. (2007). The long tail: Nischenprodukte statt Massenmarkt. München: Carl Hanser Verlag.

Antorini, Y. M.. (2009, March 26). Hypermodern consumers are doing it for themselves: The case of consumer created communities. Proceedings of the 4th International Research Days on Marketing Communications, $26-27$ March, 2009, Aarhus. Aarhus: Aarhus Business School, University of Aarhus.

Antorini, Y. M. (2007). Brand community innovation: An intrinsic case study of the adult fans of LEGO. Copenhagen: Copenhagen Business School.

Assink, M.. (2006). Inhibitors of disruptive innovation capability: A conceptual model. European Journal of Innovation Management, 9(2), 215-233.

Ballan, I. C.. (2001). Protecting music copyrights in cyberspace: Napster, MP3 and other recent litigation. Proceedings of the 2nd Annual Spring Meeting, 27-29 April 2001. Torrey Pines: The Business Law Section and the Intellectual Property Section of the State Bar of California.

BBC News. (2009, January 15). Pandora to cut off UK listeners. Retrieved from http://news.bbc.co.uk/1/hi/technology/ 7178699.stm.

Benghozi, P. J. \& Paris, T.. (2000). L’industrie de la musique à l'age de l'Internet. E-business \& Management. Special edition.

Benghozi, P. J. \& Paris, T.. (2005). La fonction distribution, au cœur du management de la culture. Proceedings of the 2005 AIMAC Conference.

Benghozi, P. J.. (2005). Mutations et articulations contemporaines des industries culturelles. Proceedings of the Journées d'économie de la culture, 12-13 January 2005.

Benghozi, P. J.. (2006 May). DRM et nouveaux modèles d'affaires pour les contenus numériques. Paris: Pole de recherche en Economie et gestion de l'Ecole Polytechnique (UMR CNRS 7176). 
Chesbrough, H.. (2006a). Open innovation: The new imperative for creating and profiting from technology. Boston: Harvard Business School Press.

Chesbrough, H.. (2006b). Open business models: How to thrive in the new innovation landscape. Boston: Harvard Business School Press.

Chesbrough, H., Vanhaverbeke, W. \& West, J.. (2008). Open innovation: Researching a new paradigm. Oxford: Oxford University Press.

Christensen, C., Anthony, S. \& Roth, E.. (2004). Seeing what's next: Using the theories of innovation to predict industry change. Boston, MA: Harvard Business School Press.

Davenport, T.H., Leibold, M. \& Voelpel, S.. (2006). Strategic management in the innovation economy: Strategy approaches and tools for dynamic innovation capabilities. Erlangen: Publicis/Wiley Corporate Publishing.

Dodgson, M., Gann D. \& Salter, M. (2008). The management of technological innovation. Oxford: Oxford University Press.

Ettlie, J. E.. (2006). Managing innovation: New technology, new products, and new services in a global economy (2nd ed.). Burlington: Elsevier Butterworth-Heinemann.

Fagerberg, J., Mowery, D.C. \& Nelson, R. R.. (2005). The Oxford handbook of innovation. Oxford: Oxford University Press.

Gaber, E., Gibbons, P., Matias, Y. \& Mayer, A.. (2006). How to make personalized web browsing simple, secure, and anonymous. Lecture Notes in Computer Science, 1318. Berlin: Springer Verlag

Hagel, J., Brown, J., \& Davison, L.. (2008, October). Shaping strategy in a world of constant disruption. Harvard Business Review, 86(10).

Hippel von, E.. (2005). Democratizing innovation. Cambridge (USA): MIT Press.

Karp. A.. (2003, January). Making money selling content that others are giving away. Communications of the ACM, 46(1), 21.

Kelly, K. (1997). New rules for the new economy. Retrieved December 02, 2006, from http://www.kk.org/newrules/contents.php.

Kotler, P., Jain, C. \& Maesincee, S.. (2002). Marketing der Zukunft: Mit Sense und Response zu mehr Wachstum und Gewinn. Frankfurt: Campus Verlag.

Kusek, D.. (2009, January 18). Music statistics for 2008. Retrieved February 07, 2009, from http://www.futureofmusicbook. com/2009/01/music- stats-for-2008-from-soundscan.

Kusek, D. \& Leonhard, G.. (2006). Die zukunft der musik: Warum die digitale Revolution die Musikindustrie retten wird. München: Musikmarkt Verlag.

Lampel, J., Bhalla, A., \& Iha, P.. (2008). Intellectual property rights and industry evolution: The case of the recorded music industry, the creative industries and intellectual property. Proceedings of the DIME International Conference, London. London: City University.

Levine, R., Locke, C., Searls, D. \& Weinberger, D.. (2001). The cluetrain manifesto: The end of business as usual. New York: Basic Books.

Lipovetsky, G. (2009, March 26). Marketing in a hypermodern society. Proceedings of the 4th International Research Days on Marketing Communications, Aarhus 26-27 March, 2009. Aarhus: Aarhus Business School, University of Aarhus.

Lohmann von, F.. (2009). How Hollywood has been trying to disrupt disruptive innovation. Eetimes. Retrieved from http://www.eetimes.com/disruption/essays/vonlohmann.jhtml.

Markides, C. C.. (2008). Game-changing strategies. San Francisco: John Wiley \& Sons Ltd.

Moyon, E. \& Lecocq, X.. (2006). La dynamique des réponses stratégiques des majors au changement institutionnel dans l'industrie de la musique. Lille: IAE de Lille, LEM.

Oliver, C.. (1991). Strategic responses to institutional processes. Academy of Management Review, 16(1), 145-179.

Popcorn, F.. (1999). Clicking: Der Neue Popcorn Report (2nd ed.). Munich: Wilhelm Heyne Verlag.

RIAA (Recording Industry Association of America). (2005, 2006, 2007, 2008). Year-end shipment statistics. Retrieved from http://www.riaa.com/keystatistics.php.

Schulmeister, G.. (2008). The third wave of computing. Reykjavik University. Retrieved from http://www.olafurandri.com/nyti/ papers2008/Ubiquitous_computing.pdf.

Schumpeter, J. A.. (1950). Capitalism, socialism and democracy (3rd ed.). New York: Harper \& Row.

Stone, B. \& Helft, M.. (2009, April 26). New York times: In developing countries, web grows without profit. Retrieved from http://www.nytimes.com/2009/04/27/technology/start-ups/27global.html?_r=1\&partner=rss\&emc=rss.

Suppappola, M.. (2004). The end of the world as we know it? The state of decentralized peer-to-peer technologies in the wake of metro-goldwin-mayer studios v. grokster. Connecticut Public Interest Law Journal, 4(1), 121-179.

Spotify. Retrieved from http://www.spotify.com.

Tidd, J. Bessant, J. \& Pavitt, K.. (2005). Managing innovation: Integrating technological, market and organizational change (3rd ed.). Chichester: John Wiley \& Sons Ltd.

Trott, P.. (2008). Innovation management and new product development (4th ed.). Harlow: Prentice Hall.

Utterback, J. M.. (1996). Mastering the dynamics of innovation. Boston: Harvard Business School Press.

Waldman, M., Rubin, A. \& Cranor, L.. (2000). Publius: A robust, tamper-evident, censorship-resistant web publishing system. Proceedings of the 9th USENIX Security Symposium August 2000.

Waters, D.. (2009). BBC: YouTube stands by UK video block. Retrieved from http://news.bbc.co.uk/1/hi/technology/7933565.stm.

Zentner, A.. (2006 April). Measuring the effect of file sharing on music purchases. The Journal of Law and Economics, 49.

(Edited by Rudy and Chris) 